\title{
Introducing Shakespeare to the fringes of Europe: The first Romanian performance of The Merchant of Venice
}

\author{
Madalina Nicolaescu \\ U niversitatea din București, Romania
} \begin{abstract}
V enice; melodrama.
\section{Introducción a Shakespeare en la periferia europea: la primera representación rumana de The Merchant of Vcnice}

ABSTRACT

Shakespeare was introduced into the Romanian Principalities between 1830 and 1855, beginning with a production of The M erchant of V enice, translated from a French adaptation of the play. This essay considers the dearth of critical attention paid to the influence of French melodrama in Southeastern Europe, and in Romania in particular; examines the circulation of Shakespearean productions in this area; and investigates the various processes of de-and re-contextualization involved in the melodramatic adaptation of The M erchant of Venice in France in the 1830s and in its translation/ performance in the Romanian Principalities in the 1850s.

KEYWORDS: Shakespeare in Romania; French adaptations; The M erchant of

RESUMEN: Shakespeare fue introducido en los Principados Rumanos entre 1830 y 1855, siendo la primera una producción de The $M$ erchant of $V$ enice, traducida a partir de una adaptación francesa de la obra. El presente trabajo considera la escasa atención crítica que se ha prestado a la influencia del melodrama francés en el sureste europeo, y en Rumanía en particular. Además, analiza la circulación de las producciones shakespearianas en esta zona, investigando los diversos procesos de descontextualización y recontextualización realizados en la adaptación melodramática de The $M$ erchant of $V$ enice en Francia en la década de 1830, y su traducción y representación en los Principados Rumanos en

\section{A Introdução de Shakespeare nas M argens da Europa: A Primeira Produção Romena de The M erchant of Venice* $^{*}$}

RESUMO: Shakespeare foi introduzido nos Principados Romenos entre 1830 e 1855, começando com uma produção de The $M$ erchant of $V$ enice, traduzido a partir de uma adaptação francesa da peça. Este ensaio considera a escassez de atenção crítica prestada à influência do melodrama francês no sudeste europeu e na Roménia em particular; examina-se a circulação de produções shakespearianas nesta região e investiga-se os vários processos de descontextualização e recontextualização envolvidos na adaptação melodramática de The $M$ erchant of V enice em França na década de 1830 e a sua tradução/ representação teatral nos Principados Romenos na década de 1850.

*Translation into Portuguese by Miguel Ramalhete. 
Nicolaescu

la década de 1850.

PALABRAS CLAVE: Shakespeare en

PALAVRAS-CHAVE: Shakespeare na Rumanía; adaptaciones francesas; The $M$ erchant of $V$ enice; melodrama.

Roménia; adaptações francesas; The

$M$ erchant of $V$ enice; melodrama.

\section{The mystery around the first Romanian Shylock performance}

While the dissemination of eighteenth-century German adaptations in Eastern Europe (mostly in the Habsburg Empire) has al ready been tackled, the spread of nineteenth-century French Romantic versions of Shakespeare has hardly been broached. ${ }^{1}$ This paper will look at the "French connection" of the transnational diffusion of Shakespeare in Eastern Europe and will focus on the Bard's early introduction into the Romanian Principalities (Wallachia and Moldavia) at a time when they were still part of the Ottoman Empire, but had recently been placed on Europe's map. This period starts with the peace of Adrianople between the Ottoman and Russian empires in 1829 and ends with another Russian-Turkish war, the Crimean War (1853-1856). It marks the beginning of modern Romanian society, when windows to Europe were eventually opened and Romanian society embarked on a speedy process of re-inventing itself. The introduction of Shakespeare in the Romanian Principalities was part of an important process of cultural import from France which made possible the break with the premodern Ottoman heritage and the redefinition of Romanian political and cultural identity in the terms of, and after the models offered by, Western societies.

As was the case in other (East)European cultures, French translations of English literature (Shakespeare included) played the role of mediators, ensuring access to English texts, in a context in which there was no direct contact with English culture. ${ }^{2}$ Earlier French rewritings of Shakespeare by Jean-François Ducis had a wide circulation in Europe, reaching Poland and Russia in the East, Spain

\footnotetext{
${ }^{1}$ Among the most important contributions on German and French adaptations see Schulze (1993, 55-74), Gibińska (2014), Minier (2014), and Nicolaescu (2014).

${ }^{2}$ On the role of French culture as European cultural mediator in the eighteenth and early nineteenth century, see Lambert $(1993,31)$. For the first Romanian translations of English literature via French versions, see Grimm (2012).
} 
and Portugal in the West or Italy in the South; they further provided the text for the earliest translations of Shakespeare in the respective languages. ${ }^{3}$ What is singular about the reception of the French Shakespeare in Romanian culture is that it occurred relatively late and did not involve Ducis's adaptations; what was introduced into the Romanian Principalities were the re-workings of the Romantic generation that rejected Ducis and the neo-classical norms associated with his "imitations." 4 While the cultural mediation and circulation of Ducis's plays has received much critical attention, the transnational dissemination of later romantic French adaptations of Shakespeare has largely been ignored. One reason for this lack of interest is the long staying power of Ducis, who was performed at the Comédie Française until late into the nineteenth century and the correspondingly tenuous hold that the Romantic Shakespeare had on the French elite stages. ${ }^{5}$ A nother reason has to do with the lack of cultural prestige of popular Shakespeare adaptations performed on Boulevard stages. ${ }^{6}$ While scholarship has paid scant attention to the Shakespeare performed on these stages, the diffusion of popular adaptations across the continent has been ignored altogether. ${ }^{7}$ This

${ }^{3}$ Ducis's adaptations were designed to re-work Shakespeare's texts so as to make them "fit" the norms and neoclassical restrictions in force in eighteenth-century France. $\mathrm{His}$ rewritings enjoyed a long lasting success on the stage of the Comédie Française until the latter half of the nineteenth century. For the major changes in plot, characters and versification introduced by Ducis to make Shakespeare acceptable to the French audience, see Willems $(2010,95-99)$ and Pemble $(2005,240-42)$. For an overview of Ducis's circulation in late eighteenth-century and early nineteenthcentury Europe, see Stokes $(2012,299)$.

${ }^{4}$ Ducis's views were powerfully contested by Victor Hugo and the other French romantic playwrights and poets in the 1830s. On Victor Hugo "as anti-Voltaire" and hence a critic of Ducis, see Willems (2010, 41-43).

${ }^{5}$ In Lambert's view, the relative failure of the Romantic Shakespeare to conquer the French stage and the persistence of the neo-classical Ducis were determined by the autonomy of the theater from the literary movements of nineteenth-century France. However, Lambert focuses almost exclusively on the elite theaters and disregards the popular ones (1993, 36-37).

${ }^{6}$ There is a recent critical movement towards the reconsideration of the theatrical innovations produced on the Boulevard stages which were long dismissed as spectacular and commercial (Thomasseau 2009).

7 Lambert acknowledges that Alexandre Dumas Sr. provided the "theatrical Shakespeare" of the nineteenth century $(1993,38)$, but does not discuss his Hamlet at Théâtre Historique. Pemble examines the Dumas-M eurice version of $\mathrm{H}$ amlet in greater details, though in a most disparaging manner (2005, 110-17). 
paper is going to focus on one of these popular melodramatic adaptations, once successful and now fallen into oblivion, and will follow its journey towards what was considered to be Europe's borderland, i.e. the Romanian Principalities. I will look at the double process of de and re-contextualization involved in reworking Shakespeare (in French and in Romanian). Particular emphasis will be placed on the cultural and political meanings first injected into Shakespeare in the French adaptation and then carried across and modified in the Romanian translation.

The first Shakespearean performance, staged in Iaşi (the capital of the Principality of Moldova) in 1850, was the Romanian version of a French adaptation of The $M$ erchant of $V$ enice, which in Romanian was entitled Shylock- sau Sânetul de singe [Shylock or the Blood Bond]. The title seemed to be subject to variation and uncertainty: the play was referred to as both The M erchant of V enice and Shylock. Unfortunately, the play text did not survive so that our analysis has to rely merely on the information provided by the review of this performance, where Shakespeare's title and the title of the adaptation were interchangeable (Burada 1975, 341). The same review described the play as having been written by the famous author Shakespeare, and it further specified that it was translated from French by A. Vasiliu. ${ }^{8}$ There is no mention of any adaptor or a translator of the Shakespearean text into French who might have given the play the title Shylock. One can infer that the Romanian public at that time was little interested in differentiating between the original and its French re-working. Hence the smooth passage from the title of the original to that of the adaptation. The Romanian translator A. Vasiliu was well-known within the Iaşi theater circles for his successful translation of Lamartelliere's adaptation of Schiller's play Die Rauber (The Bandits). Shakespeare, like Schiller and other European canonical writers (Young, Byron), was introduced to this part of Europe via French adaptation of the source text. Given the cultural

\footnotetext{
8 “Reprezentații dramei renumitului autor Sacspir, intitulată N eguțătorul din V eneția (Sânetul de Singe) ne-au dat alaltăieri o probă despre gradul si talentul actorilor nostri, nu mai puțin traducătorului din limba franceză A. Vasiliu" [The performers of the drama of the famous author Shakespeare, called The M erchant of Venice (The Blood Bond) gave us yesterday a proof of the talent of our actors and of the translator from French A. Vasiliu]. Gazeta de M oldova 101 (20 December 1851), quoted in Burada (1975, $341)$. Note that Shakespeare's play is referred to with both titles, the original title and the alternative title of the French adaptation.
} 
prestige of French, the Romanian public fully adopted the French domestication of the sources and credited the respective re-writings as representative of the original.

The same French adaptation of Shakespeare's The M erchant of Venice was retranslated into Romanian for performances in Wallachia (also called Țara Românească), the southern Romanian Principality. The 1854 production of the play in Bucharest bears a slightly different title, Shylock evreul sau Învoiala de sînge [Shylock, the Jew or the Blood Bargain]. ${ }^{9}$ This time, the translation, available in manuscript form, mentions not only the Romanian translator (A. Teulescu), but also the French author of the adaptation: Mr. D'Alboaz. The name "D'Alboaz," however, is misleading, as it is a conflation of the names of the two French authors of the adaptation, M. Du Lac and Jules-Edmond Alboise.

Romanian scholarship has largely ignored this version, first because it is an adaptation and secondly because it was impossible to identify the French source text. I. Horia Radulescu was the first critic to mention it. He discussed six early nineteenth-century Frenchbased Romanian translations of Shakespeare, tracing and comparing their respective source texts, which he identified as subsequent revisions of Pierre Letourneur's eighteenth-century version. As he did not know the source text of Shylock, Radulescu only provided basic performance-related information (1938, 260.) Alexandru Duțu has been the first scholar to discover the manuscript in the library of the Academy in 1964. He no longer includes the text under the heading of translations of Shakespeare, but relegates it to Shakespeare "adaptations." As Duțu also takes at face value the supposed author's name of "D'Alboaz," the puzzle around the French source is not solved. The manuscript has not attracted any further critical attention, mostly due to its low status as a translation of an adaptation. ${ }^{10}$

What is further intriguing about the manuscript version is the fact that it does not mention where the French text was first performed.

\footnotetext{
${ }^{9} \mathrm{~N}$ ot unlike many translations commissioned for the stage throughout the nineteenth and twentieth century, the only extant manuscript, surviving in the Library of the Romanian Academy, has never been published.

${ }^{10}$ I would like to mention the important help Fernando Cioni gave me in identifying the French adaptation which helped me find the two authors.
} 
By contrast, the French original, published in Paris in 1830, does provide a whole list of details missing in the Romanian translation: it specifies that the play is a drama (not a comedy); that it has three acts (the usual structure of melodramas) and that it was performed at Le Théâtre de la Porte Saint Martin in April 1830. Though the Romanian translation follows the original in a most faithful way, it omits this important information. It might be assumed that these data were not considered relevant to Romanian audiences, not even to the censorship committee inspecting the text in 1854, at a time of political unrest at the height of the Crimean War. ${ }^{11}$ However, there is plenty of evidence to suggest a different hypothesis. Romanian theater producers were eager to advertise the initial place of performance of a play, as its restaging also involved a transfer of cultural capital associated with the initial theater. Furthermore, the Romanian public was well familiar with the theater of Porte Saint Martin, holding it in greater regard than the Comédie Fran çaise, which was thought to be ossified and outmoded. ${ }^{12}$ Actors would regularly buy play texts of the performances staged there, convinced they would succeed in Romanian theaters (Ollanescu 1981, 231). Both actors and audience were equally aware of the involvement of this theater not only in the artistic revolution of the Romantics but also in the political events of the 1830 July Revolution and later on in the 1848 events. $^{13}$ Therefore, the omission of the name of the French theater and the conflation of the authors' names might well have been a deliberate ruse to hoodwink the censors, known to suppress anything associated with political protest.

Nevertheless, the fuzziness around the title and authorship of the play begs the question about the knowledge that the Romanian audience had of Shakespeare at the time of his introduction onto the Romanian stage. How much of a canonical author was Shakespeare considered? How well known were his plays? Did the Shakespeare bardolatry precede knowledge of his plays, as had been the case in Hungary? (Davidházi 1993; 1998). What were the consequences of the French mediation for the early reception of Shakespeare in this

\footnotetext{
${ }^{11}$ For detailed information on how the censorship in the theater worked at that time, see Radulescu (1935, 42-44).

${ }^{12}$ See note 22 below.

${ }^{13} \mathrm{M}$ any members of the audience had spent their student days in Paris at the time and even actively participated in the revolutionary events.
} 
part of Europe? To answer some of these questions, I will first look at the early material traces of Shakespeare's works in the two Romanian Principalities. Next, I will take up the discussion of the French adaptation of The $M$ erchant of $V$ enice and look into the reasons it resonated with the Romanian public twenty-five years after its first performance in Paris. Particular attention will be paid to the melodramatic reworking that Shakespeare's play underwent in French. Did this mediation impede or facilitate the early Romanian reception of Shakespeare?

\section{Shakespeare's early routes of entry into the Romanian Principalities}

The first important shipments of Shakespeare's works in German and French translation into this part of Europe took place in 1840 and were ordered by two major book stores, Bell and Henning, located in Iaşi. The records show that earlier on, in 1838, Adolf Henning, a teacher of German at an elite school in Iaşi ("Institutul de baieti de pe dealul Miroslavei") had ordered several copies of Shakespeare's "Werke" in the Schlegel and Tieck translation for his students (Ionita 2007, 112). In 1841, a shipment of plays by Victor Hugo, Dumas, and Casimir Delavigne also included Ducis's works (I onita 2007, 157). Given the late arrival of the Ducis imitations to the Romanian Principalities, at a time when the reaction of the French romantics against Ducis and the neoclassical theater had already been embraced in Romania, Ducis's imitations of Shakespeare had little resonance with the public. Further shipments of Ducis's versions were discontinued after 1842. Instead, there was a sudden demand for Shakespeare, with several shipments of his works in French being registered with both book vendors, Bell and Henning. Over the next years, the import of Shakespeare's plays in both French and German continued at an increasing pace (Ionita 2007, $104,112,119,130)$. Unfortunately, similar data are unavailable on the import of Shakespeare books to Bucharest, but the pattern of importing Shakespearean texts must have been similar. There is one difference, however: Tara Romaneasca was almost exclusively a francophone country, with only few German books imported here. No German book was reviewed in the major journals of the time. Consequently, we can safely infer that fewer editions of Shakespeare in German were circulated here than were in Moldova. 
Operatic adaptations provided another venue for the introduction of Shakespeare to the Romanian audience. ${ }^{14}$ The archives of the year 1840, when the first important shipment of Shakespeare's plays took place, also include an invoice for Rossini's opera Otello in French. By this date foreign opera troupes (with German, Italian or French singers) along with French and German theater troupes had become hugely fashionable and were generously financed by the authorities; in stark contrast, the newly established Romanian theaters were left unfunded. Though accused of impeding the development of the local Romanian theater, foreign troupes played an important role as transnational agents disseminating Western culture in Europe's borderland. ${ }^{15}$ The success of the 1842 performances in French of Rossini's 0 tello and of Bellini's Capuleti et $M$ ontecchi stimulated the audience's interest in Shakespeare and created a market for his plays. It probably determined an increase in the orders for Shakespeare's works in French translation the same year as well. Furthermore, the operatic performances can be said to have precipitated the translation of 0 thello and Romeo and Juliet through Letourneur's French versions and their publication in $1848 .^{16}$

One reason for the success of the operatic versions of Shakespeare's plays lies in the high status that the opera enjoyed at the time. ${ }^{17}$ Romanian audiences enthusiastically embraced the Italian

\footnotetext{
${ }^{14}$ For the relationship between opera, melodramatic adaptations and Shakespeare, see Sanders (2012, 188-97).

${ }^{15}$ The first Italian opera was set up in Moldova in 1837. A highly successful opera troupe was directed by the German soprano Henriette Karl, who used to sing at the Prussian court, another by the Greek manager Papanicola who had set up the first opera in Istanbul. Sometimes French troupes would not come down from Paris but from Odessa, Russia, thereby setting up an Eastern European connection (Burada 1975, 129). On foreign companies in the Romanian Principalities in the early nineteenth century and on the cosmopolitan audience they played for, see Ollanescu (1981, 240-43), Burada (1975, 350-59), and Boia (2015, 19).

${ }^{16}$ Letourneur was known to the Romanian public from his translations of Young's poems, which were initially as popular as Byron's.

17 There was a craze for the Italian opera in all the important cities of the two principalities, including provincial cities like Craiova and Pitesti. All of the works of Rossini, Bellini, Donizetti, Karl Maria von Weber, Verdi and later on Wagner were performed in Italian, French or German. Authorities strongly subsidized and encouraged foreign opera companies who were eager to bring celebrities to this part of the world. (Liszt came in 1846, A dela Ristori in the early 1860s, etc.).
} 
opera as an emblem of their radical break with the Ottoman traditions and as an icon of their new affiliation with European modernity. Translations into Romanian of opera librettos, including of course Rossini's 0 tello, were a big market success in the $1850 \mathrm{~s}$ (Cornea 1966, 55-58). The Romanian passion for Rossini's Otello lasted until the 1870s, when Salvini's and Rossi's performances of Shakespeare's 0thello reoriented the public's interest towards Shakespeare's play. In 1845, before the publication of the first Romanian translation of 0 thello, the bulk of the Romanian public was familiar only with Rossini's version of the story. Even theater critic and dramatist Cezar Bolliac wrote a detailed review of a performance of the opera in Bucharest and mentioned Shakespeare only in passing, as a rewriter of Cinthio (Bolliac 1836). Although Bolliac was the first Romanian critic to write an essay on Shakespeare in 1836 (Bolliac 1836; Grigorescu 1971, 4), his knowledge of the plays was rather derivative and his essay largely reproduced Hugo's views on Shakespeare's genius as expressed in the preface to Cromwell. In conclusion, the opera can be said to have lent prestige and popularity to Shakespeare's plays.

For all the huge prestige that Hugo enjoyed in the Romanian Principalities at the time, ${ }^{18}$ his exalted views on Shakespeare did not play an important role in Romanian literary life. ${ }^{19}$ Shakespeare was only named once, in a sequence of authors that starts with Schiller. While Romanian writers were enthusiastic supporters of Hugo, Dumas and Delavigne and of their defeat of the neoclassic tradition, ${ }^{20}$ the use of Shakespeare in this clash did not have any

${ }^{18}$ Almost all of Hugo's plays were translated and performed in the 1840 s and $1850 \mathrm{~s}$ (Petrea 45, 159).

${ }^{19}$ Surprisingly, the preface to Cromwell was neither translated into Romanian nor discussed in literary debates. Likewise, the battle of H ernani, i.e. the dispute between the two literary camps in France in which Hugo had mobilized Shakespeare's example, did not have any resonance with Romanian writers (Cornea 2008, 227).

20 “Pe ideea asta, o gloată de scriitori a năbușit pe scena Frantii, au introdus pe teatru sistema lui Sakispir, Ghete si Siler. Dar nu tuturora le e dat sa scrie ca Sakispir sau Siler [...] si opintirile lor n-au făcut decit sa strălucească adevarații poeți si scriitori precum Hugo, Delavigne, Dumas. Aceștia înțelegînd duhul parterului ce se săturase de tragediile înalțate ale lui Corneil, elegiacice ale lui Rasin si filozofice ale lui Volter, și-au croit o sistemă mai potrivită pentru veacul lor [...]" [Working on this idea, a band of writers have flooded the French stages and have introduced into the theater the system of Shakespeare, Goethe and Schiller. But not everybody has the gift to write like Shakespeare and Schiller [...] and their stumbling and fumbling have set off 
particular resonance in Romanian cultural life. The Romanian Romantic Movement did not emerge in a conflict against the norms and values of the Enlightenment nor could the figure of Shakespeare be enlisted in any cultural or political struggle, the way he was deployed in other parts of Europe. Consequently, he got relatively glossed over. He was an "other," placed at a double remove from Romanian culture. His reception needed heavy mediation via more familiar theatrical genres.

\section{The appeal of the melodramatic version of The Merchant of Venice}

Why did the Romanian actors, going to Paris in the early 1850 s to get updated on the latest theatrical hits, accept an adaptation of The $M$ erchant of $V$ enice that had been staged twenty years before? Why did they choose an adaptation and not a more "faithful" and prestigious translation of Shakespeare such as Alfred de Vigny's The $M$ erchant of V enice (1827) or his 0 thello (1829)?

One obvious reason is that the Romanian actors were more interested in the popular performances on the Boulevard stages, where Shakespeare was present, albeit in heavily appropriated and re-written versions that sometimes bore little resemblance to the original (Pemble 2005, 98-100). ${ }^{21}$ Théophile Gautier was critical of these frivolous "imitations," which both grossly domesticated Shakespeare and further combined him with material drawn from Gothic writers, such as Ann Radcliffe and Lewis (Gautier 1859, 19; Pemble 2005, 101; Clark-Wehinger 2005, 67). Gérard de Nerval particularly objected to such eclecticism, fearing that the vulgarization of Shakespeare in the popular "imitations" might

the quality of true poets and writers like Hugo, Delavigne, Dumas. These, having understood that the spirit of the parterre has got tired of the elevated tragedies like Corneille's, or the elegiac ones of Racine, or the philosophical ones of Voltaire, have fashioned a new system, better suited to their age] (Negruzzi 1986, 514-15).

${ }^{21}$ Not all French critics were fully aware of the difference between the "faithful" versions (still heavily purged and re-written to suit the French taste) and the mere "imitations." Thus Le Figaro of A pril 201830 cannot distinguish between De Vigny's "faithful" translation for the stage and Du Lac and Alboise radical re-writing of The M erchant of V enice (Bassan 1984, 41). For the French tendency to take adaptations as representative of the original Shakespearean play see Morse $(2004,113)$. 
undermine the Romantic reformation of the French theater that had taken Shakespeare for its model (Clark-Wehinger 2005, 97, 131).

The Shylock staged at Le Théâtre de la Porte de Saint Martin provided an instance of the eclecticism which the French literary circles objected to, as it combined the Shakespearean plot with fashionable elements of the "drame sociale," the three unities of the French classic theater, plus some Gothic violence in the ending. Nerval dismissed the Shylock figure, who does get his pound of flesh in the end, "as a caricature of Shakespeare's character, ruled merely by passions and instinct" (Clark-Wehinger 2005, 98). The performance, however, proved successful and was staged in France well into the $1840 \mathrm{~s}^{22}$

I would like to advance three reasons that might have prompted the Romanian actors to choose this Shakespearean adaptation over other more "faithful" versions, which enjoyed the critics' support. To begin with, it is a prose translation; secondly, it has the appeal of the melodrama, thus ensuring a quick box office success; and thirdly, it could mobilize revolutionary meanings on the Romanian stages.

Du Lac and Alboise's prose version was easier to translate than a more "faithful" translation in verse, such as de Vigny's Le M archand de $V$ enise. The Romanian language was still in the early stages of modernization and hardly lent itself to the translation of French alexandrines. The 1855 translation of Dumas's version of $\mathrm{H}$ amlet in verse proved a disaster and compromised the performance of a most expected play. At the same time, Romanian translators had already acquired significant experience translating the colloquial prose of melodramas.

The melodramatic format must have appealed to the actors since they were aware that this highly emotional style was essential for the survival of the newly established theaters in the Romanian Principalities, where melodrama had strong appeal, and would ensure the allegiance of a large and varied audience. The clichés of the genre, much maligned by literary critics, nonetheless facilitated cultural adaptation and absorption of Western into Eastern culture.

${ }^{22}$ An important key to its success was the spirited performance of Shylock's role by Bocage, one of the most important and innovating actors of the Boulevard theaters, who could masterfully combine the old declamatory style with the new "natural acting," learned from the English players. 
Romanian theaters were particularly receptive to the second wave of melodramas written in the late 1920's and '30's by Victor Ducange and his school. ${ }^{23}$ These plays tried to occupy a middle ground between the "classic" type that emerged in postrevolutionary France and a more temperate approach that recuperated themes of the Enlightenment related to social and political issues, such as tolerance, justice, opposition to tyranny. ${ }^{24}$ This type of drama fits well with the "half romantic" nature of the Romanian literature in the 1830-1860 period, where features of the Enlightenment and Romanticism coexisted and interacted, both being regarded as revolutionary departures from the dominant traditions (Nemoianu 1984, 125-26). Romanian theater professionals and public alike appreciated the political and civic potential of these "liberal" melodramas and lumped them together with Romantic prose dramas by Hugo and Dumas, all initially performed at the theater of La Porte de Saint Martin in the $1830 \mathrm{~s}^{25}$

One more reason for the appeal of melodrama to the Romanian public was the conservative patriarchal values enshrined by the style (Przybos 1987). These values were in consonance with the views embraced in the Romanian society of the time and provided a common ground for the otherwise diverging French and Romanian social realities. The melodramatic adaptation of The $M$ erchant of $\checkmark$ enice applied a radical re-writing of the moral make-up of Bassanio and Portia. The latter, renamed Nerissa, is no longer a wealthy heiress, but a destitute poetess who lacks the money to bury her mother. Portia alias Nerissa does not disguise herself and therefore does not transgress against the traditional gender roles which had been reinforced by the French Restauration. ${ }^{26}$ She still wields a controversially strong power as a popular poetess, who can

\footnotetext{
${ }^{23}$ For the importance of distinguishing between various types of melodrama and the changes it underwent, see Thomasseau (2009). British critics have been mostly interested in the earlier, "classic" melodrama which emerged in the postrevolutionary years and was exported to Britain in the Napoleonic period (Cox 2007; Moody 2004; Bratton 2007).

${ }^{24}$ Relatively little has been written on the "second wave" of melodramas and its social oriented character; for best analyses see Thomasseau (2009), and Le Hir (1992).

${ }^{25}$ On the hybridization of melodramas and the Romantic drama of Hugo and Dumas, see Le Hir (1992, 125-29) and Cooper (2005, 456-63).

${ }^{26}$ Melodramas promoted the reinforcement of traditional definitions of femininity that was predicated on women's dependence on the husband and father (Perrot 1994).
} 
manipulate the "people" into rebelling against the Duke. Bassanio is Antonio's son (Antonio is the arch-villain in the play, yet does not appear on the stage); he is no longer the profligate wooer but Portia's/ Nerissa's secret financial supporter who asks Shylock for a loan to help her out. In a typically melodramatic manner, the adaptation suppresses the complex interlocking between commerce and romance in Shakespeare's play and rewrites the heroes as unambiguously virtuous victims. Bassanio adopts the sacrificial position of a Christ-like figure: he and not Shylock is the one who suggests the blood deal and offers his own piece of flesh as a warrant.

Family values are further reinforced; Shylock is a most loving father, not short on sympathy and fellow-feeling ${ }^{27}$ and initially forgives his daughter's transgressive feelings towards a Christian. Jessica is not a rebel and reciprocates her father's love with filial piety: she does not actually consent to her elopement and has to be abducted. Jessica attends the trial in order to defend her father and places herself between him and the enraged people.

The choice of an older version of the play over a more fashionable one could further be explained from a political perspective. Paris was a fascinating cultural capital for the Romanian intelligentsia on account of the combination of the political and artistic emancipation they found there. Romanian actors identified this political edge in the plays of the 1830s, staged around the July revolution, rather than in the repertoires of the late 1840s. It was in that earlier period that the relation between Romanticism and revolution was established in the theater. As Anne Ubersfeld $(1968,20)$ has pointed out, to be a Romantic meant to be against the government-in particular, to be against its fierce political and cultural censorship. Boulevard theaters -one of them being Le Théâtre de la Porte Saint Martin, where Shylock was performed-became hot spots in the July Revolution, with theater people fighting on the barricades (Duby and A riès 1994, 462).

${ }^{27}$ In the first act, several poor people praise his acts of charity and project him as a Robin Hood figure who rips off the rich to help the poor: "Le jeune pauvre: Oui, Shylock est dur aux riches, mail il est bon, humain pour nous" (Du Lac and Alboise 1830, 2; my emphasis). 
The Shylock of this version is reconfigured as a spokesman of the Droits de I'Homme and of the great ideals of the 1789 French Revolution of égalité fraternité- liberté. He confesses to his daughter early in the play:

J'étais né avec une âme tendre et généreuse [...] et le juif comme le chrétien était un frère à mes yeux; [...] je croyais qu'une âme grande, une figure humaine me rendait l'égal des autres hommes; je ne savais pas que le titre d'esclave était attaché aux vêtements de ma nation. (Du Lac and Alboise, 1830; 14; my translation and my emphasis)

[I was born with a loving and generous soul [...] and the Jew just like the Christian was a brother to me [...] I believed that a large soul and a human appearance would render me the equal of other men; I did not know that the label "slave" had been attached to the clothes of my nation.]

Shylock's thirst for revenge is further re-designed in keeping with the notion in the Declaration of the right to resistance and to redress for injury, notions which Benjamin Constant further developed. ${ }^{28}$

What is particularly interesting about this adaptation is that Shylock's personal action of revenge is coupled with a more impersonal legal initiative. He proposes to the Jewish community to use their financial clout and oblige the Duke and the senate to pass a law that secures what the French text calls "Ies franchises de notre nation" [the rights/ freedoms of our nation]. Du Lac and Alboise conflate here the two Venetian outsiders-Othello and Shylock. ${ }^{29}$ Shylock finds himself in the position of being asked to save the Venetian state not militarily but financially. The play expands the suggestion in Shakespeare's play of an alternative civic community around the synagogue (Lupton 2005) and introduces a council of the Jewish community which debates the loan to be granted to the state. In a most unexpected strategy of turning tables and propelling the underdog into a position of power, Du Lac and Alboise have the Duke come to the Jewish council to beg for assistance. Shylock, as leader of his community, proposes that in exchange of the loan given to Venice, the Jewish community should ask for the adoption of a

\footnotetext{
${ }^{28}$ I have discussed this aspect at large ( $\mathrm{Nicolaescu} 2011$ ).

${ }^{29}$ For the discussion of similar conflations of Othello and Shylock, see Bassi $(2011,239$ 42).
} 
new law that would secure their rights to equal and nondiscriminating treatment and to the inviolability of property:

[...] le ciel remet encore une fois le destin de Venise en nos mains.

Ces patriciens si fiers, ce sénat si superbe, le doge lui-même implorent aujourd'hui notre appui. Esclaves soumis, hier nous courbions humblement nos fronts devant eux. Les rôles ont changé. Ce sont les maîtres qui prient maintenant, et qui attendent avec anxiété que nous leur tendions une main secourable. Que faut-il faire? Laisser consommer leur ruine, et fuir avec nos trésors loin d'un pays où chacun de nos services est payé par une persécution nouvelle, ou bien oublier le passé, les sauver encore, mais en assurant cette fois et pour toujours les franchises de notre nation! Parlez, mes frères, que décidez vous?

[The heavens have once again put the fate of Venice into our hands. These proud patricians, this great senate, the doge himself beg us to come to their help. Yesterday we were still humble slaves who bowed down before them, today the roles have changed. Now the masters beg us and wait anxiously for us to give them a helping hand. What shall we do? Shall we let them be ruined and run away with our fortunes far away from a country where our charitable acts are rewarded with renewed persecutions, or shall we forget the past, forgive them, yet this time take action to secure once and for all the freedoms/rights of our nation? Say brethren, what is your decision?] (Du Lac and Alboise, 1830, 5-51; my translation and my emphasis)

It is beyond doubt that the French political reconfiguration of Shylock must have appealed to the Romanian theater people during the Russian occupation in the early 1850s. Shylock is hardly identified with the Jewish minority in the Romanian Principalities, whose numbers were just beginning to grow and became a target of anti-Semitic feelings. The Shylock of this version is read as a champion for equality and democratic rights and as such shares many features with the revolutionaries of the generation of FortyEight. In this period, the "Forty-Eighters" (i.e. the participants in the 1848 Revolution) at home and in exile were organizing a follow-up to the action of national and political liberation initiated in 1848. The revolutionaries were determined to use the Crimean War for the opportunities it opened up to liberate the country from the Russian protectorate and to negotiate a greater autonomy from the Ottoman Empire. The revolutionaries' agenda further included the recognition by the Sublime Porte of a new republican government 
and the extension of political rights and liberties granted to the Romanian population. In spring 1854 there broke out a series of uprisings against the Russians (the "barbarians from the North") (Barbu 2003, 11); an army in the southern part of the country had been organized and a republican government was in the making. The revolutionaries' plans fell through when Austria invaded the country and made a separate settlement with the Ottoman Empire. Given this political context, Shylock's active stance and refusal to bow down to oppression in Du Lac and Alboise's adaptation must have resonated deeply with the Romanian audience.

The Romanian translation of "les franchises de notre nation" introduced a slight change that pointed directly to the local political events. The word "franchises" is translated with "eliberare"meaning not merely freedoms/ rights but "liberation." This coincides with the fact that at that time the new revolutionary government and General Magheru, who was in charge of organizing the military insurrection, had advanced "a new Constitution of the Romanian Principalities, drawn up on the basis of the desires of the Romanian people, the progress of time and the security of the Ottoman Empire" (Barbu 2003, 76). The similarity between the two proposals must have had a titillating impact on the Romanian audience.

The translation of the play smuggled onto the Romanian stage a rich human rights vocabulary. References to equality, the rights of the individual, protection against unjust laws, as well as legal terms like contract, convention, warrant, not only supplied a "foreignizing" effect (Venuti 1995) but also conveyed an indirect political statement in favor of reform and modernization. The success of the first production of a Shakespearean play on the Romanian stages was therefore less indebted to the prestige of the Bard and more to the innovative cultural and political transfer that the radical French adaptation performed on the Romanian stage.

To conclude: this paper has been discussing the French route of Shakespeare's circulation across Europe to its south-eastern border. Contact with Shakespeare occurred later here than in Central Europe or Russia and coincided with the dissemination of Romantic French theater and Italian opera. What was first performed in Bucharest was a French melodramatic re-writing that radically reconfigured both the plot and the Shylock figure. I have been trying to argue that it is this very re-writing, taken as representative of the original, which 
best fitted the cultural and political context of a Shakespeare performance in a part of Europe that was trying to free itself both from the Russian occupation and the Ottoman rule. Given the heavy mediation of the Shakespearean play, what was mostly transferred to the Romanian stage had less to do with Shakespeare's England and much more with modern nineteenth-century French culture.

\section{References}

Barbu, Paul Emanoil. 2003. "Studiu introductiv." In Actiuni sociale si politice romanesti in anii 1853-1854 [Romanian Social and Political Documents in the Years 1853-1854], 5-25. Bucuresti: Editura A cademiei Romane.

Bassan, Fernande. 1984. Alfred de Vigny et la ComédieF rançaise. Tübingen and Paris: Gunter Narr Verlag and Editions Jean Michel Place.

Bassi, Shaul. 2011. "Barefoot to Palestine: The Failed Meetings of Shylock and Othello." In V isions of Venice in Shakespeare, edited by Laura Tossi and Shaul Bassi, 231-50. Farnham and Burlington: Ashgate.

Boia, Lucian. 2015. Cum s-a românizat România [How did Romania get Romanian.] Bucuresti: Humanitas.

Bolliac, Cezar. 1836. "Sakespir." Curiosul. 1: 30-31.

Bratton, Jacky. 2007. "Romantic Melodrama." In The Cambridge Companion to British Theatre 1730-1830, edited by Jane Moody, and Daniel Quinn, 11527. Cambridge: Cambridge University Press.

Burada, Teodor T. 1975. Istoria Teatrului in M oldova [History of the Theater in Moldavia]. New edition. Bucuresti: Minerva.

Clark-Wehinger, Alice. 2005. William Shakespeare et Gérard de N erval: Le thêâtre romantique en crise, 1830-1844. Paris: Harmattan.

Cooper, Barbara T. 2005. "French Romantic Tragedy." In A Companion to Tragedy, edited by Rebecca Bushnell, 452-68. Oxford: Blackwell.

Cornea, Paul. 1966. D e la A lecsandrescu la Eminescu, aspecte, figuri, idei. [From Alecsandri to Eminescu, Aspects, Figures, Ideas] Bucuresti: Editura Pentru Literatură.

- - . 2008. O riginile romantismului românesc [The Origins of Romanian Romanticism], $2^{\text {nd }}$ edition, Bucuresti: Polirom.

Cox, Jeffrey N. 2007. "The Death of Tragedy; or the Birth of M elodrama." In The Performing Century. Nineteenth Century Theatre's History, edited by Tracy C. Davis, and Peter Holland, 161-81. Basingstoke: PalgraveMacMillan. 
Nicolaescu

D'Alboaz. 1854. Seilok evreul sau invoiala de singe. D rama in 4 acte. A. Teulescu, trans. The Library of the Romanian A cademy. MS. 5864.

Davidházi, Péter. 1993. "Providing Texts for a Literary Cult. Early Translations of Shakespeare in Hungary." In European Shakespeares. Translating Shakespeare in the Romantic A ge, edited by Dirk Delabastita, and Lieven D'Hulst. 147-62. A msterdam/ Philadelphia: John Benjamins.

- - - 1998. The Romantic Cult of Shakespeare: Literary Reception in Anthropological Perspective. London: Palgrave Macmillan.

Drace-Francis, Alex. 2006. The M aking of M odern Romanian Culture. Literacy and the Development of $\mathrm{N}$ ational Identity. London and New York: I.B. Tauris.

Du Lac, M. and Alboise, Jules-Edmond. 1830. Shylock, drame en trois actes, imité de Shakespeare. Paris: Bezou.

Duby, George, and Philippe Ariès, eds. 1985-1987. H istoire de la vie privée. V ol 4. De la Révolution à la Grande guerre. Paris: Seuil.

Duțu, Alexandru. 1964. Shakespeare in Rumania. A Bibliographical Essay. Bucuresti: Meridiane.

Espagne, Michele. 2013. "La notion de transfert culturel." Revue Sciences/ Lettres 1. Accessed May 30, 2017. DOI: 10.4000/ rsl.219.

Gautier, Théophile. 1859. “De l'état actuel du théâtre." In H istoire de l'art dramatique depuis vingt-cinq ans. Vol 1, 15-20. Paris: Editions Hetzel.

Gibińska, Marta. "Polonia est divisa in partes tres: Shakespeare in the Polish culture of the 19th Century." In "In double trust": Shakespeare in Central Europe, edited by Jana Bžochová-Wild, 7-28. Bratislava: VŠMU, 2014.

Grigorescu, Dan. 1971. Shakespeare in cultura romana moderna. Bucuresti: Minerva.

Grimm, Petre. 2012. Scrieri de istorie literara [Writing of Literary History]. Edited by Liana Muthu. Cluj: Eikon Scriptor.

Hugo, Victor. 1968. “Préface" Cromwell. 62-108. Paris: Flammarion.

Ionita, Alexandra. 2007. Carte franceza in M oldova pana la 1859 [French Books in Moldova until 1859]. Iaşi: Demiurg.

Lambert, José. 1993. "Shakespeare en France au tournant du XVIIle siècle. Un dossier européen." In European Shakespeares. Translating Shakespeare in the Romantic A ge, edited by Dirk Delabatista, and Lieven D'Hulst, 22-45. Amsterdam/ Philadel phia: John Benjamins.

Le Hir, Marie-Pierre. 1992. Le Romantisme aux enchères: Ducange, Pixérécourt, Hugo. Amsterdam: John Benjamins.

Lupton, Julia Reinhard. 2005. Citizens-Saints. Shakespeare and Political Theology. Chicago: Chicago University Press. 
Mayer, David. 2004. "Encountering Melodrama." In The Cambridge Companion to Victorian and Edwardian Theatre, edited by Kerry Powell. 145-64. Cambridge: Cambridge University Press.

Minier, Marta. 2014. "Uprooting Shakespeare. A Historical Survey of Early to Institutionalised Hungarian Shakespeare Translation." In "In double trust": Shakespeare in Central Europe, edited by Jana Bžochová-Wild, 2951. Bratislava: VŠMU.

Moody, Jane. 2004. “The Theatrical Revolution, 1776-1843." In The Cambridge History of British Theatre. Vol. 2: 1660-1895, edited by Joseph Donohue, 199-216. Cambridge: Cambridge University Press.

Morse, Ruth. 2004. "Monsieur Macbeth: from Jarry to Ionesco." Shakespeare Survey 57: 112-25.

Negruzzi, Costache. 1986. Teatru, vol 3. Edited by Liviu Leonte. Bucuresti: Minerva.

Nemoianu, Virgil. 1984. The Taming of Romanticism. European Literature and the A ge of Biedermeier. Boston: Harvard University Press.

Nicolaescu, Madalina. 2011. "Re-writing Venice and Radicalizing Shylock: Nineteenth-Century French and Romanian Adaptations." In V isions of Venice in Shakespeare, edited by Laura Tossi and Shaul Bassi, 215-31. Farnham and Burlington: A shgate.

- - . "Shakespeare in Habsburg Transylvania." In Renaissance Shakespeares: Shakespeare Renaissances. Proceedings of the Ninth World Shakespeare Congress, edited by Martin Prochaska, Michael Dobson, Andreas Hoefele, 211-19. N ewark: University of Delaware Press, 2014.

Ollanescu, C. Dimitrie. 1981. T eatrul la romani [Romanian Theater]. Edited by Cristina Dumitrescu. Bucuresti: Editura Eminescu.

Pemble, John. 2005. Shakespeare Goes to Paris. How the Bard Conquered France. London and New York: Hambledon and London.

Perrot, Michelle. 1987. "La Famille triomphante." In Histoire de la vie privée. Vol 4. De la Révolution à la Grande guerre, edited by Philippe A riès and George Duby, 93-103. Paris: Seuil.

Petrea, Elena. 2009. V ictor Hugo in cultura româna. Iasi: Editura Universitatii Alexandru Ioan Cuza.

Przybos, Julia. 1987. L'entreprise mél odramatique. Paris: Jose Corti.

Radulescu, Ion Horia. 1935. Contributiuni la istoria teatrului din Muntenia 1833-1853. [Contributions to the History of the Theater in Muntenia]. Bucuresti: Institutul de Istorie Literara si Folclor.

- - - 1938. "Les intermédiaires français de Shakespeare en Roumanie." Revue de littérature comparée 18: 252-71. 
Nicolaescu

Sanders, Julie. 2012. "Shakespeare and Music." In Shakespeare in the Nineteenth Century, edited by Gail Marshall, 187-205. Cambridge: Cambridge University Press.

Schulze, Brigitte. 1993. "Shakespeare's Way into the West Slavic Literatures and Cultures." In European Shakespeares: Translating Shakespeare in the Romantic Age, edited by Dirk Delabastita and Lieven D'Hulst, 55-74. Amsterdam: John Benjamins.

Shakespeare, William. 1996. The M erchant of Venice. Edited by Molly Maureen Mahood. Cambridge: Cambridge University Press.

Stokes, John. 2012. "Shakespeare in Europe." In Shakespeare in the N in eteenth Century, edited by Gail Marshall, 296-314. Cambridge: Cambridge University Press.

Thomasseau, Jean-Marie. 2009. M élodramatiques. Saint Denis: Presses Universitai res de Vincennes.

Ubersfeld, Anne. 1968. Introduction to "Préface" Cromwell, by Victor Hugo. 17-51. Paris: Flammarion.

Venuti, Lawrence. The Translator's Invisibility: A History of Translation. London and New York: Routledge, 1995.

Vigny, Alfred de. 1920. Théâtre. Vol 2. Paris: Flammarion. (Le More de Venise 31-219: Le Marchande de Venise 219-324).

Willems, Michele. 2010. “Voltaire." In V oltaire, Goethe, Schlegel, Coleridge Great Shakespeareans, vol. III, edited by Roger Paulin, 5-44. London: Bloomsbury.

\footnotetext{
How to cite this article:

Nicolaescu, Madalina. "Introducing Shakespeare to the fringes of Europe: The first Romanian performance of The M erchant of V enice." SED ERI 27 (2017): 129-48.

A uthor's contact: madalinanicolaescu@gmail.com

Postal address: English Department - University of Bucharest - Str Pitar Mos 7-10 Bucuresti 990023, Romania
} 